\title{
Serum Matrix Metalloproteinases MMP-2 and MMP-3 Levels in Dialysis Patients Vary Independently of CRP and IL-6 Levels
}

\author{
Gloria A. Preston Cheri V. Barrett David A. Alcorta Susan L. Hogan \\ Lesley Dinwiddie J. Charles J ennette Ronald J. Falk \\ Division of Nephrology and Hypertension, Department of Medicine, and Department of Pathology and \\ Laboratory Medicine, University of North Carolina at Chapel Hill, Chapel Hill, N.C., USA
}

\section{Key Words}

C-reactive protein $\cdot$ Hemodialysis · Inflammation . Interleukin-6 - Matrix metalloproteinases - Peritoneal dialysis

\begin{abstract}
Background: Patients on chronic hemodialysis or peritoneal dialysis often develop an inflammatory state that causes morbidity and mortality. Cross-sectional studies of dialysis patients have determined that C-reactive protein (CRP) is a predictor of morbidity. Little is known as to whether CRP, cytokines, such as IL- 6 and IL- $1 \beta$ that stimulate the synthesis of CRP, or matrix metalloproteinases (MMPs) are markers of inflammation in patients on dialysis. Methods: We assayed by ELISA serum levels of MMP-2, MMP-3, IL-6 and CRP in healthy individuals and in patients with pre-end-stage renal disease (pESRD, $n=$ $10)$, peritoneal dialysis ( $P D, n=11$ ), hemodialysis (HD, $n=$ 17) and renal transplant (TX, $n=10)$. Results: MMP-2 was significantly elevated before dialysis, perhaps indicative of progressive chronic renal sclerosis. MMP-3 was markedly elevated in hemodialysis patients but not in pESRD or PD patients, and may be related to the hemodialysis process and/or accelerated atherogenesis in these pa-
\end{abstract}

\begin{tabular}{ll}
\hline KARGER & ( 2002 S. Karger AG, Basel \\
0028-2766/02/0924-0817\$18.50/0 \\
$\begin{array}{l}\text { Fax +4161306 12 34 } \\
\text { E-Mail karger@karger.ch } \\
\text { www.karger.com }\end{array}$ & $\begin{array}{l}\text { Accessible online at: } \\
\text { www.karger.com/journals/nef }\end{array}$
\end{tabular}

tients. IL-6 was significantly elevated in all patient groups, including $\mathrm{pESRD}$ patients. There were no statistically significant differences in CRP levels among the study groups. CRP correlated with IL-6, but not with MMP-2 or MMP-3. Conclusions: The data indicate that there are measurable differences in the expression of MMPs within the dialysis patient population. Because dialysis can be associated with local and systemic inflammation, increased levels of MMP-3 in the hemodialyis group may be a reflection of gene stimulation induced by inflammatory cytokines and should be considered as a marker of chronic, local inflammation.

Copyright $\odot 2002$ S. Karger AG, Basel

\section{Introduction}

Inflammation in patients with end-stage renal disease is associated with malnutrition, cardiovascular morbidity and death. Inflammatory stimuli elicit the release of cytokines that cause many systemic changes. These changes include increased synthesis and release of acute-phase proteins, such as C-reactive protein (CRP), and the suppression of acute-phase proteins, such as albumin [1]. Serum levels of CRP have previously been reported to be

Gloria A. Preston, $\mathrm{PhD}$

Division of Nephrology, University of North Carolina, Chapel Hill

346 MacNider Hall, CB \# 7155

Chapel Hill, NC 27599 (USA)

Tel. +1 919966 2570, Fax +1 919966 4251, E-Mail Gloria_Preston@med.unc.edu 
a better predictor of low serum albumin levels than nutritional parameters in both hemodialysis and peritoneal dialysis patients [2-4]. Moreover, hypoalbuminemia, primarily attributed to malnutrition, in dialysis patients is a predictor of death [5]. CRP levels can be used to predict risk for coronary heart disease in individuals with atherosclerosis [6].

Yet, CRP is a non-specific serum indicator of inflammation [7, 8]. Cytokines released from injured tissues stimulate the liver to synthesize CRP and other acute phase proteins. The signal transduction pathways regulating CRP induction by cytokines are not fully delineated. Levels of CRP correlate with those of interleukin-6 (IL-6); however, IL-6 alone induces only moderate increases in CRP gene expression, while IL-6 in combination with interleukin-1 $\beta$ (IL-1 $\beta$ ) results in a marked synergistic enhancement of CRP expression [9]. IL-6 is a reliable marker of disease severity and inflammatory organ injury in rheumatoid arthritis (RA) [10]. IL-6 is reportedly responsible for acute complications in patients with endstage renal disease such as fever, headache and hypotension [11-15].

Matrix metalloprotease (MMP) gene expression is regulated by cytokines such as IL-6, IL-1 $\beta$, and tumor necrosis factor- $\alpha$ (TNF- $\alpha)[16,17]$. Excessive or inappropriate expression of MMPs has been associated with progressive renal injury. MMPs are elevated in association with both glomerular sclerosis $[18,19]$, and interstitial kidney fibrosis [20]. MMP-2 is involved in the regulation of the mesangial cell inflammatory phenotype in a model of acute mesangial proliferative glomerulonephritis [21-23]. Increased levels of MMP-3 have been detected in sera from patients with mesangial proliferative glomerulonephritis, IgA nephropathy and active lupus nephritis [24]. In general, MMPs contribute to the pathogenesis of many tissue destructive processes, such as cardiovascular diseases [25-28].

The purpose of this study was to identify markers other than CRP for inflammation in patients with renal disease, particularly those on dialysis. Markers other than CRP might facilitate the detection of low level, localized inflammation that is not detected by increases in CRP. We determined serum levels of CRP, MMP-2 (gelatinase A), MMP-3 (stromelysin-1) and IL-6 in a cross-sectional sample set, including pre-end-stage renal disease ( $p E S R D)$, peritoneal dialysis (PD), hemodialysis (HD), and renal transplant (TX) patients.

\section{Methods}

Patients were selected by accessibility from within the UNC system. The study included 31 females and 27 males. HD patients were dialyzed thrice weekly with a polysulfone hollow-fiber dialyzer (Fresenius F-80B; Fresenius USA, Walnut Creek, Calif., USA). Dialyzers were reused up to 20 times using an automated bleach and formalin method (Fresenius DRS-4, Walnut Creek, Calif., USA). PD patients performed their exchanges either manually or with the aid of an automated cycler (Baxter Healthcare Corporation, Deerfield, Ill., USA; Fresenius USA, Concord, Calif., USA). Many of the cycler patients performed a midday exchange manually.

\section{Experimental Protocol}

Blood was drawn into separator tubes and serum was collected and stored at $-20^{\circ} \mathrm{C}$. Blood was drawn immediately prior to dialysis, for those patients. The levels of total serum MMP-2 (both free and complexed to TIMP-2), MMP-3 (total), and IL-6 were determined using commercially available ELISA kits (MMP-2 and MMP-3, Amersham Life Science, Buckinghamshire, England; IL-6, Biosource International, Inc., Camarillo, Calif., USA). The assays were run in duplicate and were performed in accordance with the manufacturer's instructions. The upper/lower detection limits for MMP-2 was 1.5$24 \mathrm{ng} / \mathrm{ml}$; for MMP-3 was 3.75-120 ng/ml; and for IL-6 was $0.16-$ $10 \mathrm{pg} / \mathrm{ml}$. When serum concentrations exceeded the limits of detection, the serum sample was diluted and reevaluated. Serum CRP levels were determined by the McLendon Clinical Laboratories of UNC Hospitals using the COBAS Integra system from Roche Diagnostics with the lower limit of detection set at $0.5 \mathrm{mg} / \mathrm{dl}$.

\section{Statistical Analysis}

Analysis of variance and Kruskal-Wallis tests were used for comparing values across patient groups. Bonferroni tests were used to qualify comparisons between the groups. Because of the skewed distributions of values for IL-6 and MMP-3, natural log transformations of these values were used for statistical analysis and graphic displays.

\section{Results}

In order to assess the relative levels of circulating MMPs and compare them to IL- 6 and CRP concentrations, assays were performed on sera from 10 healthy subjects, $10 \mathrm{pESRD}, 17$ hemodialysis patients (HD), 11 peritoneal dialysis patients (PD), and 10 transplant patients (TX) (table 1). Transplant patients had stable renal function with no evidence for acute rejection with creatinine levels that ranged from 0.9 to $3.8 \mathrm{mg} / \mathrm{dl}$ (table 1). Serum creatinine levels in pESRD patients ranged from 25.8 to $2.4 \mathrm{mg} / \mathrm{dl}$ (table 1). Patients' diagnoses are given in table 1 . The spectrum of diseases represented in the study was purposefully selected to include hypertension (HTN), glomerulonephritis (GN), diabetes mellitus (DM), IgA nephropathy, focal segmental glomerulosclerosis, lupus nephritis, diabetes, and interstitial nephritis. 
Table 1. Individual patient information

\begin{tabular}{|c|c|c|c|c|c|c|c|}
\hline $\begin{array}{l}\text { Patient } \\
\text { No. }\end{array}$ & Category & $\begin{array}{l}\text { ESRD } \\
\text { diagnosis }\end{array}$ & $\begin{array}{l}\text { MMP2 } \\
\mathrm{ng} / \mathrm{ml}\end{array}$ & $\begin{array}{l}\text { MMP3 } \\
\mathrm{ng} / \mathrm{ml}\end{array}$ & $\begin{array}{l}\text { CRP } \\
\mathrm{mg} / \mathrm{dl}\end{array}$ & $\begin{array}{l}\text { IL-6 } \\
\mathrm{pg} / \mathrm{ml}\end{array}$ & $\begin{array}{l}\text { Creatinine } \\
\mathrm{mg} / \mathrm{dl}\end{array}$ \\
\hline 1 & pESRD & $\mathrm{DM}$ & 1,050 & 63.2 & 0.5 & 1.1 & 3.6 \\
\hline 2 & pESRD & Int Neph & 1,300 & 96.8 & 0.5 & 3.7 & 7.6 \\
\hline 3 & pESRD & $\mathrm{DM}$ & 1,075 & 56.0 & 1.3 & 4.4 & 5.1 \\
\hline 4 & pESRD & HTN & 1,240 & 55.2 & 0.5 & 7.5 & 9.9 \\
\hline 5 & pESRD & $\mathrm{DM}$ & 838 & 57.6 & 0.5 & 1.4 & 5.6 \\
\hline 6 & $\mathrm{pESRD}$ & $\mathrm{DM} / \mathrm{HTN}$ & 1,375 & 30.0 & 0.8 & 7.6 & 4.8 \\
\hline 7 & pESRD & SLE & 970 & 464.0 & 0.5 & 5.0 & 2.4 \\
\hline 8 & pESRD & $\mathrm{DM}$ & 1,245 & 216.0 & 4.2 & 8.4 & 5.0 \\
\hline 9 & pESRD & HTN & 935 & 136.0 & 0.5 & 0.9 & 8.3 \\
\hline 10 & pESRD & Int Neph & 710 & 60.0 & 15.5 & 26.4 & 25.8 \\
\hline 11 & HD & $\mathrm{DM}$ & 950 & 339.7 & 0.8 & 10.4 & \\
\hline 12 & HD & PKD & 805 & 363.5 & 0.8 & 3.8 & \\
\hline 13 & HD & cong. Hyd & 30 & 375.5 & 0.5 & 2.2 & \\
\hline 14 & HD & SLE & 990 & 373.8 & 0.5 & 5.4 & \\
\hline 15 & HD & HTN & 710 & $1,408.2$ & 0.5 & 3.0 & \\
\hline 16 & HD & HTN & 1,005 & 368.7 & 8.4 & 13.6 & \\
\hline 17 & HD & HTN & 805 & 911.7 & 1.5 & 2.6 & \\
\hline 18 & HD & HTN & 770 & 360.1 & 1.0 & 3.0 & \\
\hline 19 & HD & HTN & 510 & 355.8 & 6.8 & 12.2 & \\
\hline 20 & HD & PKD & 620 & 269.9 & 0.5 & 3.0 & \\
\hline 21 & HD & HTN & 1,070 & 208.0 & 5.1 & 10.8 & \\
\hline 22 & HD & MGN & 665 & 236.4 & 0.5 & 2.4 & \\
\hline 23 & HD & psGN & 675 & 436.5 & 0.9 & 3.8 & \\
\hline 24 & HD & FSGS & 925 & 159.9 & 0.5 & 1.6 & \\
\hline 25 & HD & $\mathrm{DM}$ & 550 & 95.5 & 0.5 & 2.9 & \\
\hline 26 & HD & HTN & 1,065 & 240.8 & 0.6 & 2.4 & \\
\hline 27 & HD & $\mathrm{RCCa}$ & 755 & 111.8 & 0.5 & 3.8 & \\
\hline 28 & PD & SLE & 1,200 & 256.8 & 0.5 & 1.4 & \\
\hline 29 & PD & HTN & 850 & 104.8 & 0.5 & 12.5 & \\
\hline 30 & PD & $\mathrm{DM}$ & 1,230 & 58.4 & 0.5 & 1.4 & \\
\hline 31 & PD & IgA Neph & 1,290 & 238.4 & 0.5 & 29.0 & \\
\hline 32 & PD & PGN & 1,245 & 111.2 & 0.5 & 2.7 & \\
\hline 33 & PD & HTN & 510 & 40.8 & 1.3 & 5.4 & \\
\hline 34 & PD & unknown & 465 & 18.4 & & 1.4 & \\
\hline 35 & PD & unknown & 975 & 45.6 & 6.0 & 24.2 & \\
\hline 36 & PD & unknown & 560 & 192.0 & 0.5 & 25.4 & \\
\hline 37 & PD & SCA & 445 & 96.8 & 14.3 & 25.0 & \\
\hline 38 & PD & GN & 675 & 280.0 & 0.5 & 5.0 & \\
\hline 39 & $\mathrm{TX}$ & HTN & 555 & 137.6 & 0.5 & 0.5 & 0.9 \\
\hline 40 & $\mathrm{TX}$ & HTN & 915 & 262.4 & 0.5 & 1.7 & 3.0 \\
\hline 41 & $\mathrm{TX}$ & HTN & 710 & 248.0 & 0.5 & 1.2 & 1.2 \\
\hline 42 & $\mathrm{TX}$ & IgA neph & 1,160 & 336.0 & 0.5 & 1.7 & 3.2 \\
\hline 43 & $\mathrm{TX}$ & HTN & 1,210 & 208.8 & 0.5 & 1.4 & 2.5 \\
\hline 44 & $\mathrm{TX}$ & HTN & 1,260 & 114.4 & 0.5 & 0.9 & 1.6 \\
\hline 45 & $\mathrm{TX}$ & FSGS & 710 & 240.0 & 0.5 & 0.1 & 1.4 \\
\hline 46 & $\mathrm{TX}$ & CPGN & 1,135 & 240.0 & 0.5 & 1.4 & 2.3 \\
\hline 47 & $\mathrm{TX}$ & HTN & 690 & 312.0 & 0.5 & 1.2 & 2.6 \\
\hline 48 & $\mathrm{TX}$ & HTN & 1,305 & 249.6 & 0.5 & 0.2 & 1.4 \\
\hline
\end{tabular}

Matrix Metalloproteinases in Renal and

Nephron 2002;92:817-823 


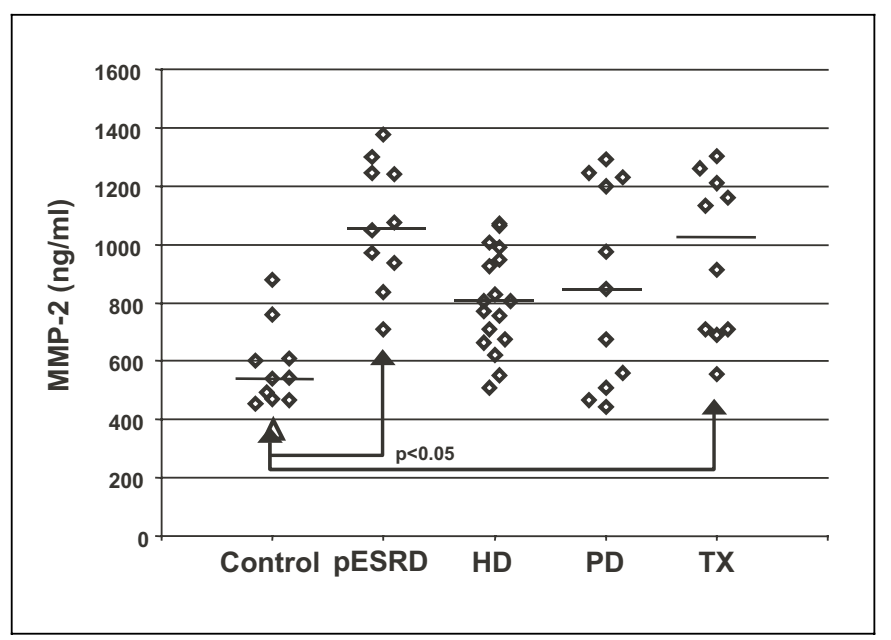

Fig. 1. The mean serum values of MMP-2 in normal controls, patients not yet on dialysis, $\mathrm{pESRD}(\mathrm{n}=10)$, patients on hemodialysis, HD ( $\mathrm{n}=17)$, patients on peritoneal dialysis, $\mathrm{PD}(\mathrm{n}=11)$, and transplant, TX patients $(n=10)$. MMP-2 levels were significantly elevated in pESRD and TX patients, compared to controls $(\mathrm{p}<$ 0.05).

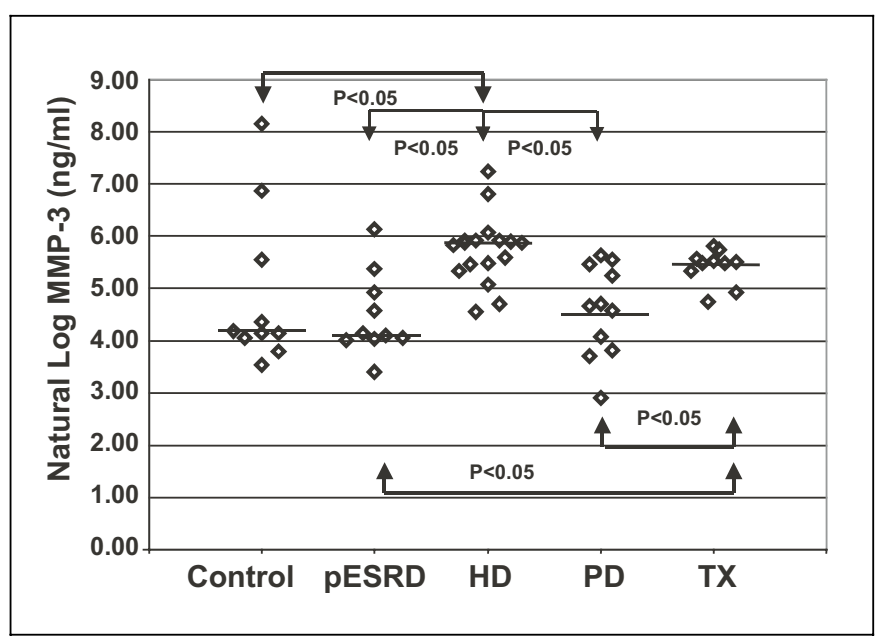

Fig. 2. The mean values of the natural log of MMP-3 in normal controls, patients not yet on dialysis, $\mathrm{pESRD}(\mathrm{n}=10)$, patients on hemodialysis, HD $(\mathrm{n}=17)$, patients on peritoneal dialysis, PD $(\mathrm{n}=11)$, and transplant, TX patients $(\mathrm{n}=10)$. MMP-3 levels were significantly elevated in HD patients, compared to controls $(\mathrm{p}<0.05)$. Levels in HD patients were higher than in PD patients and in TX patients were higher than in PD and pESRD patients $(\mathrm{p}<0.05)$.

Table 2. Analysis of variance and Kruskal-Wallis tests were used for comparing values across patient groups and Bonferroni tests for comparing between groups

\begin{tabular}{|c|c|c|c|c|c|c|}
\hline & $\begin{array}{l}\text { Control } \\
(\mathrm{n}=10)\end{array}$ & $\begin{array}{l}\mathrm{pESRD} \\
(\mathrm{n}=10)\end{array}$ & $\begin{array}{l}\text { HD } \\
(n=17)\end{array}$ & $\begin{array}{l}\text { PD } \\
(\mathrm{n}=11)\end{array}$ & $\begin{array}{l}\mathrm{TX} \\
(\mathrm{n}=10)\end{array}$ & $\begin{array}{l}\text { ov. } \\
\text { p value }\end{array}$ \\
\hline $\mathrm{CRP}^{1}, \mathrm{mg} / \mathrm{dl}$ & $\begin{array}{l}\text { normal } \\
\text { range }<0.5\end{array}$ & $0.5(0.8)$ & $0.6(0.5)$ & $0.5(0.8)$ & $0.5(0)^{2}$ & 0.784 \\
\hline IL-6 ${ }^{1,3}, \mathrm{pg} / \mathrm{ml}$ & $0.09(0.8)$ & $4.7(6.2)^{*, \wedge}$ & $3.0(2.8)^{*, \wedge}$ & $5.4(24)^{*, \wedge}$ & $1.2(0.9)^{*}$ & 0.001 \\
\hline MMP-2, ng/ml & $542(140)$ & $1,063(310)^{*}$ & $805(275)$ & $850(720)$ & $1,025(500)^{*}$ & 0.001 \\
\hline $\mathrm{MMP} 3^{3}, \mathrm{ng} / \mathrm{ml}$ & 64 (199) & $62(80)$ & $356(138)^{*, \wedge, \#}$ & $105(192)^{\wedge}$ & $244(54)^{\#}$ & 0.002 \\
\hline
\end{tabular}

* Different from control $(\mathrm{p}<0.05), \wedge$ different from TX $(\mathrm{p}<0.05)$; ${ }^{*}$ different from $\mathrm{p}$-ESRD $(\mathrm{p}<0.05)$.

$1 \quad$ CRP and IL-6 levels correlate overall, $r=0.667(p=0.0001)$.

2 Not analyzed due to no variance (values reported as $<0.5$ ).

3 Due to skewed distribution, data transformed by the natural $\log$ was analyzed.

High Blood Levels of MMP-2 during pESRD and in Transplant Patients

Measured levels of MMP-2, both free and complexed TIMP-2, are presented in figure. 1. Each symbol represents an individual patient and each bar represents the mean for that group. The medians and quartile intervals are given in table 2. Serum MMP-2 levels were significantly higher in pESRD patients, individuals with diminished renal function but not yet on dialysis, with a mean of $1,073.8 \pm 215.4 \mathrm{ng} / \mathrm{ml}, \mathrm{p}<0.05$, compared to healthy individuals at $582.5 \pm 139.3 \mathrm{ng} / \mathrm{ml}$. MMP-2 levels in patients on HD $(805.9 \pm 173.9 \mathrm{ng} / \mathrm{ml})$ or PD $(858.6 \pm$ $342.6 \mathrm{ng} / \mathrm{ml}$ ) were slightly elevated, compared to control values $(582.5 \pm 139.3 \mathrm{ng} / \mathrm{ml})$, but these differences were not statistically significant. In the TX patient group, MMP-2 was significantly elevated $(965 \pm 280.0 \mathrm{ng} / \mathrm{ml}$, $\mathrm{p}<0.05)$ compared to control values. 


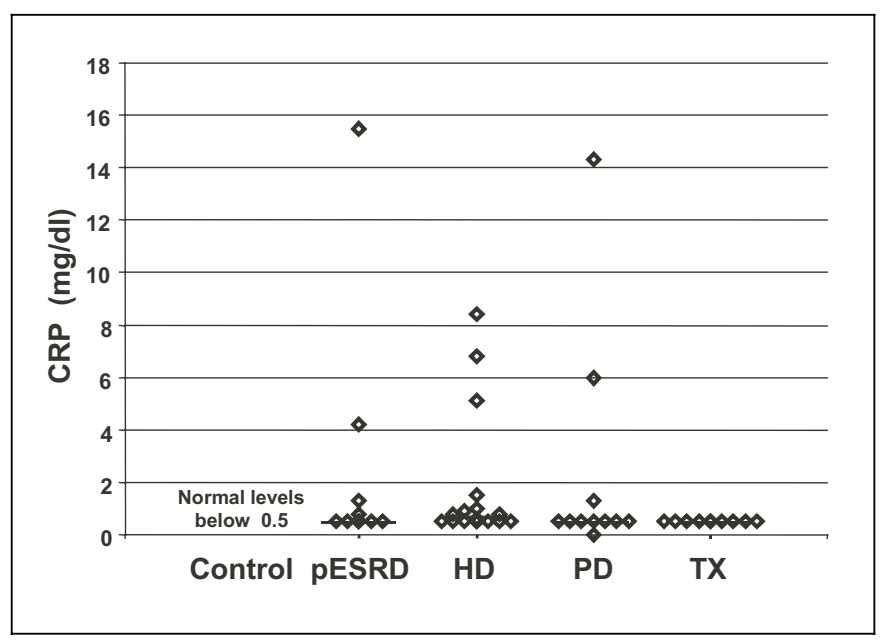

Fig. 3. The mean serum values of CRP in patients not yet on dialysis, $\operatorname{pESRD}(n=10)$, patients on hemodialysis, HD $(n=17)$, patients on peritoneal dialysis, $\mathrm{PD}(\mathrm{n}=11)$, and transplant, TX patients $(\mathrm{n}=10)$. There were no significant differences in CRP levels among any of the study groups. CRP levels in control patients were not done (ND).

\section{High Blood Levels of MMP-3 in Hemodialysis \\ Patients}

The natural logs of the values for MMP-3 (measuring total MMP-3) were used for statistical analysis due to the wide range in values and are shown in figure. 2. When comparisons were made between the control group and each of the renal groups, pESRD, HD, PD, and TX groups, only the HD patients had statistically higher levels of MMP-3. The mean value for MMP-3 was increased in the HD patients to $5.7 \pm 0.66 \mathrm{ng} / \mathrm{ml}, \mathrm{p}<0.05$ compared to $4.9 \pm 1.5 \mathrm{ng} / \mathrm{ml}$ in the control group. The medians and quartile intervals are shown in table 2. When renal groups only were compared, MMP-3 levels in HD patients (5.7 $\pm 0.66 \mathrm{ng} / \mathrm{ml}, \mathrm{p}<0.05)$ were significantly higher than levels in pESRD patients $(4.47 \pm 0.80 \mathrm{ng} / \mathrm{ml}, \mathrm{p}<0.05)$ and PD patients $(4.58 \pm 0.88 \mathrm{ng} / \mathrm{ml}, \mathrm{p}<0.05)$. TX patients had significantly higher MMP-3 levels $(5.4 \pm 0.34 \mathrm{ng} / \mathrm{ml}$, $\mathrm{p}<0.05)$ than PD $(4.58 \pm 0.88 \mathrm{ng} / \mathrm{ml})$ or pre-ESRD patients $(4.47 \pm 0.80 \mathrm{ng} / \mathrm{ml})$.

\section{IL-6 Was Significantly Elevated in All of the Patient Groups}

All of the renal groups had statistically significant increases in IL-6 levels (natural log) as compared to controls $(\mathrm{p}<0.05)$ (fig. 3 ; table 2). Elevated levels were detected in pESRD $(1.53 \pm 1.1 \mathrm{pg} / \mathrm{ml})$, PD $(1.70 \pm$ $1.27 \mathrm{pg} / \mathrm{ml}), \mathrm{HD}(1.10 \pm 0.66 \mathrm{pg} / \mathrm{ml})$, and TX $(0.18 \pm$

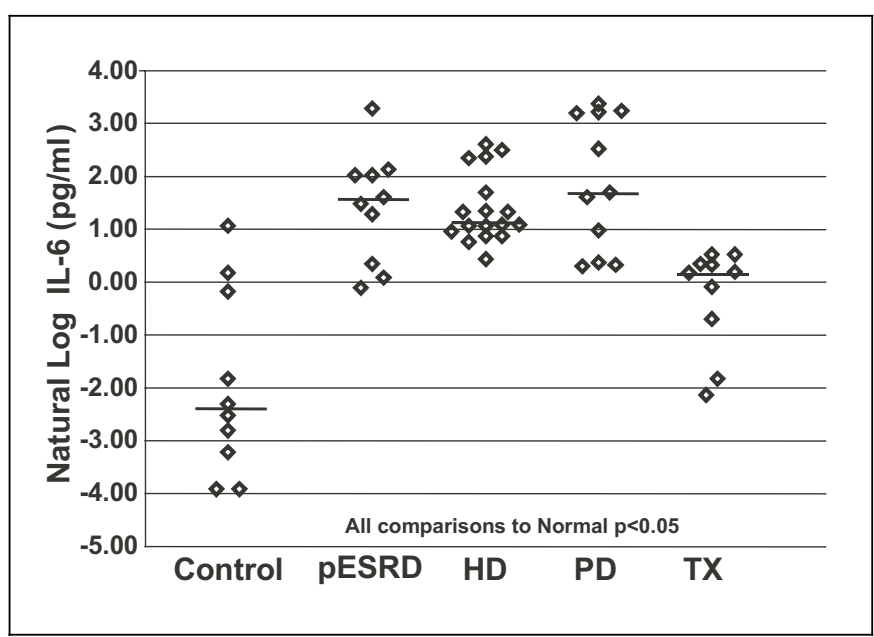

Fig. 4. The mean values of the natural log of serum values of IL-6 in normal controls, patients not yet on dialysis, pESRD $(\mathrm{n}=10)$, patients on hemodialysis, HD $(\mathrm{n}=17)$, patients on peritoneal dialysis, $P D(n=11)$, and transplant, TX patients $(n=10)$. IL-6 levels were significantly elevated in all renal groups, compared to controls $(\mathrm{p}<$ 0.05). Levels in $\mathrm{pESRD}, \mathrm{PD}$ and HD patients were higher than in TX patients $(\mathrm{p}<0.05)$.

$0.97 \mathrm{pg} / \mathrm{ml})$, as compared to the control group $(-2.4 \pm$ $1.74 \mathrm{pg} / \mathrm{ml}$ ). Additional statistical comparisons among the renal patient groups showed a significantly lower level of IL-6 in the TX group, than in the remaining groups, pESRD, HD, and PD patients.

\section{CRP Levels}

There were no statistically significant differences in CRP levels among the study groups (fig. 4; table 2). However, there were individuals within the pESRD, HD, and PD groups with elevated CRP levels. When all markers and all samples in these groups were examined for statistical linkage, IL-6 and CRP levels were the only pair that correlated overall.

\section{Discussion}

It is clinically apparent that, in some patients, insertion of vascular grafts for hemodialysis results in substantial local and systemic inflammation. Inflammation is generally monitored by following changes in levels of CRP, cytokines and chemokines. CRP elevation may only represent the end stage of substantial inflammation and other inflammatory markers may be more sensitive indicators of early inflammation injury, at least in our hemodialysis patients. The studies presented here revealed 
increased levels of MMP-3 levels in hemodialysis patients, compared to peritoneal dialysis, kidney transplant and pre-ESRD patients. Of all 48 patients evaluated in this study, 12 patients had MMP-3 levels above $325 \mathrm{mg} / \mathrm{dl}$ and, of these 12, 10 were on HD (table 1). IL-6 levels were also elevated in these patients, but not all had increased CRP. We propose that monitoring MMP-3 levels may provide an indicator of inflammation-related changes occurring specifically in HD patients. We were surprised to see that IL-6 levels were elevated in most patients, which might be a reflection of their general state of health prior to transplant.

The dissociation of CRP and MMP-3 levels in the HD patients may be a reflection of localized inflammation at the site of vascular access rather than a systemic process seen in critically ill patients who have high CRP levels. This pattern would be similar to that seen in patients with RA in which elevated MMP-3 levels were reflective of localized synovial inflammation [29, 30]. Patients with vascular disorders have been shown to display increased levels of MMP-3, and endothelial venous and arterial cells can produce MMP-3 when activated by TNF- $\alpha$ [31]. CRP levels of many patients in our studies were within normal range, similar to earlier findings by McIntrye et al. [32]. Furthermore, it has been reported that CRP serum levels correlated stronger with the degree of hypoalbuminemia in HD patients than systemic inflammation [4].

MMP-3 expression gene regulation is responsive to IL$1 \beta$, TNF- $\alpha$, epidermal growth factor (EGF), and TGF- $\alpha$ in epithelial cells [33]. Interestingly, plasma TNF- $\alpha$ and IL$1 \beta$ concentrations were found to be higher in hemodialyzed patients compared to peritoneally dialyzed patients [34].

Although serum levels of CRP, produced primarily by hepatocytes, are linked to IL-6 levels, CRP expression may require specific combinations of cytokines IL-6, TNF- $\alpha$ and IL-1 $\beta$ and in some cases they act in concert with various steroid hormones [35, 36]. Thus, CRP ex- pression in response to IL-6 is not strictly linked and induction of CRP expression may require additional factors [37]. Indeed, we found that IL-6 serum levels were increased in those patients with higher MMP-3 in the absence of CRP. Determination of the site of derivation of the MMPs and IL-6 may explain this uncoupling, i.e., if only limited arterial sites are affected then hepatocytes may not be responsive.

The differences among the groups raise additional questions that need to be considered. For example, are elevated MMP-3 levels in HD patients an indicator of accelerated atherogenesis, believed to occur during dialysis? [38]. In contrast to MMP-3, MMP-2 was not elevated in the HD patients. Instead, MMP-2 was significantly elevated in both pre-ESRD and transplant patients. MMP-2 has been linked to the onset of sclerosis [19], and our data suggest that a similar phenomenon might be occurring in pre-ESRD and transplant patients. Other published results described increases in MMP-2 associated with the development of a mesangial cell inflammatory phenotype' associated with progressive glomerulosclerosis [21]. Slightly higher levels of MMP-2 and MMP-3 found in our TX group, as compared to PD and pESRD groups, correspond to reports by Rodrigo et al. that MMP-2 and MMP3 were elevated in transplant patients [39]. However, all of the transplant patients studied here had stable graft function.

In conclusion, our data demonstrate that MMP-3 may be a clinically useful indicator of an inflammatory process in hemodialysis patients. Our data do not allow determination of the site at which the MMPs are produced, factors such as the type of vascular access, unrecognized infections, or variability in responses to the dialyser used may mediate the elevation of MMPs. To evaluate better the association of MMP levels with a spectrum of renal failure and dialysis patients, a prospective longitudinal study is underway.

\section{References}

1 Pannen BH, Robotham JL: The acute-phase response. New Horiz 1995;3:183-197.

2 Kaysen GA, Stevenson FT, Depner TA: Determinants of albumin concentration in hemodialysis patients. Am J Kidney Dis 1997;29:658668.

3 Yeun JY, Kaysen GA: Acute phase proteins and peritoneal dialysate albumin loss are the main determinants of serum albumin in peritoneal dialysis patients. Am J Kidney Dis 1997; 30:923-927.
4 Owen WF, Lowrie EG: C-reactive protein as an outcome predictor for maintenance hemodialysis patients. Kidney Int 1998;54:627-636.

5 Sharma AP, Gupta A, Sharma RK, Agarwal DK, Sural S, Wardhe DJ: Does serum albumin at start of continuous ambulatory peritoneal dialysis (CAPD) or its drop during CAPD determine patient outcome? [In process citation]. Adv Perit Dial 2000;16:119-122.
6 Zimmermann J, Herrlinger S, Pruy A, Metzger $\mathrm{T}$, Wanner C: Inflammation enhances cardiovascular risk and mortality in hemodialysis patients. Kidney Int 1999;55:648-658.

7 Stahl WM: Acute phase protein response to tissue injury. Crit Care Med 1987; 15:545-550.

8 Dowton SB, Colten HR: Acute phase reactants in inflammation and infection. Semin Hematol 1988;25:84-90. 
9 Zhang D, Jiang SL, Rzewnicki D, Samols D, Kushner I: The effect of interleukin-1 on Creactive protein expression in Hep3B cells is exerted at the transcriptional level. Biochem $\mathrm{J}$ 1995;310:143-148.

10 Ito A, Itoh Y, Sasaguri Y, Morimatsu M, Mori Y: Effects of interleukin-6 on the metabolism of connective tissue components in rheumatoid synovial fibroblasts. Arthritis Rheum 1992;35: 1197-1201.

11 Nakamoto Y, Imai H, Yasuda T, Wakui H, Miura AB: A spectrum of clinicopathological features of nephropathy associated with POEMS syndrome. Nephrol Dial Transplant 1999;14:2370-2378.

12 Kaul H, Girndt M, Sester U, Sester M, Kohler $\mathrm{H}$ : Initiation of hemodialysis treatment leads to improvement of T-cell activation in patients with end-stage renal disease. Am J Kidney Dis 2000;35:611-616.

13 Yoshizaki K, Matsuda T, Nishimoto N, Kuritani T, Taeho L, Aozasa K, Nakahata T, Kawa $\mathrm{H}$, Tagoh H, Komori T et al: Pathogenic significance of interleukin-6 (IL-6/BSF-2) in Castleman's disease. Blood 1989;74:1360-1367.

14 Henderson LW: Symptomatic hypotension during hemodialysis. Kidney Int 1980;17:571576.

15 Wang P, Ba ZF, Cioffi WG, Bland KI, Chaudry IH: Hepatocellular dysfunction after severe hypotension in the absence of blood loss is associated with the increased IL-6 and PGE2. J Surg Res 1998;80:136-142.

16 Borden P, Heller RA: Transcriptional control of matrix metalloproteinases and the tissue inhibitors of matrix metalloproteinases. Crit Rev Eukaryot Gene Expr 1997;7:159-178.

17 Kossakowska AE, Edwards DR, Prusinkiewicz C, Zhang MC, Guo D, Urbanski SJ, Grogan T, Marquez LA, Janowska-Wieczorek A: Interleukin-6 regulation of matrix metalloproteinase (MMP-2 and MMP-9) and tissue inhibitor of metalloproteinase (TIMP-1) expression in malignant non-Hodgkin's lymphomas. Blood 1999;94:2080-2089.

18 Davies M, Martin J, Thomas GJ, Lovett DH: Proteinases and glomerular matrix turnover. Kidney Int 1992;41:671-678.

19 Akiyama K, Shikata K, Sugimoto H, Matsuda M, Shikata Y, Fujimoto N, Obata K, Matsui H, Makino H: Changes in serum concentrations of matrix metalloproteinases, tissue inhibitors of metalloproteinases and type IV collagen in patients with various types of glomerulonephritis Res Commun Mol Pathol Pharmacol 1997;95: 115-128.
20 Norman JT, Lewis MP: Matrix metalloproteinases (MMPs) in renal fibrosis. Kidney Int Suppl 1996;54:S61-63.

21 Turck J, Pollock AS, Lovett DH: Gelatinase A is a glomerular mesangial cell growth and differentiation factor. Kidney Int 1997;51:13971400.

22 Turck J, Pollock AS, Lee LK, Marti HP, Lovett $\mathrm{DH}$ : Matrix metalloproteinase 2 (gelatinase A) regulates glomerular mesangial cell proliferation and differentiation. J Biol Chem 1996; 271:15074-15083.

23 Lovett DH, Johnson RJ, Marti HP, Martin J, Davies M, Couser WG: Structural characterization of the mesangial cell type IV collagenase and enhanced expression in a model of immune complex-mediated glomerulonephritis. Am J Pathol 1992;141:85-98.

24 Kotajima L, Aotsuka S, Fujimani M, OkawaTakatsuji M, Kinoshita M, Sumiya, M, Obata $\mathrm{K}$ : Increased levels of matrix metalloproteinase- 3 in sera from patients with active lupus nephritis. Clin Exp Rheumatol 1998;16:409_ 415.

25 Galis ZS, Sukhova GK, Lark MW, Libby P: Increased expression of matrix metalloproteinases and matrix degrading activity in vulnerable regions of human atherosclerotic plaques. J Clin Invest 1994;94:2493-2503.

26 Bini A, Itoh Y, Kudryk BJ, Nagase H: Degradation of cross-linked fibrin by matrix metalloproteinase 3 (stromelysin 1): Hydrolysis of the gamma Gly 404-Ala 405 peptide bond. Biochemistry 1996;35:13056-13063.

27 YeS, Humphries S, Henney A: Matrix metalloproteinases: Implication in vascular matrix remodelling during atherogenesis. Clin Sci (Colch) 1998;94:103-110.

28 Shapiro SD: Matrix metalloproteinase degradation of extracellular matrix: Biological consequences. Curr Opin Cell Biol 1998;10:602608.

29 Ribbens C, Andre B, Jaspar JM, Kaye O, Kaiser MJ, De Groote D, Malaise MG: Matrix metalloproteinase-3 serum levels are correlated with disease activity and predict clinical response in rheumatoid arthritis. J Rheumatol 2000;27:888-893.
30 Ribbens C, Martin Y, Porras M, Franchimont N, Kaiser MJ, Jaspar JM, Damas P, Houssiau FA, Malaise MG: Increased matrix metalloproteinase-3 serum levels in rheumatic diseases: Relationship with synovitis and steroid treatment. Ann Rheum Dis 2002;61:161-166.

31 Hanemaaijer R, Koolwijk P, le Clercq L, de Vree WJ, van Hinsbergh VW: Regulation of matrix metalloproteinase expression in human vein and microvascular endothelial cells: Effects of tumour necrosis factor alpha, interleukin 1 and phorbol ester. Biochem J 1993;296: 803-809.

32 McIntyre C, Harper I, Macdougall IC, Raine AE, Williams A, Baker LR: Serum C-reactive protein as a marker for infection and inflammation in regular dialysis patients. Clin $\mathrm{Ne}$ phrol 1997;48:371-374.

33 Solomon A, Li DQ, Lee SB, Tseng SC: Regulation of collagenase, stromelysin, and urokinasetype plasminogen activator in primary pterygium body fibroblasts by inflammatory cytokines. Invest Ophthalmol Vis Sci 2000;41: 2154-2163.

34 Zbroch E, Malyszko J, Wolczynski S, Hryszko $\mathrm{T}$, Mysliwiec M: Concentration of leptin in patients on hemodialysis and peritoneal dialysis. Pol Arch Med Wewn 1999;101:503-508.

35 Baumann H, Jahreis GP, Morella KK: Interaction of cytokine- and glucocorticoid-response elements of acute-phase plasma protein genes. Importance of glucocorticoid receptor leve and cell type for regulation of the elements from rat alpha 1-acid glycoprotein and betafibrinogen genes. J Biol Chem 1990;265: 22275-22281.

36 Baumann H, Jahreis GP, Morella KK, Won KA, Pruitt SC, Jones VE, Prowse KR: Transcriptional regulation through cytokine and glucocorticoid response elements of rat acute phase plasma protein genes by $\mathrm{C} / \mathrm{EBP}$ and JunB. J Biol Chem 1991;266:20390-20399.

37 Szalai AJ, van Ginkel FW, Wang Y, McGhee JR, Volanakis JE: Complement-dependent acute-phase expression of C-reactive protein and serum amyloid P-component. J Immunol 2000;165:1030-1035.

38 Lonnemann G: The quality of dialysate: An integrated approach. Kidney Int 2000;58 (suppl 76):S112-119.

39 Rodrigo E, Lopez-Hoyos M, Escallada R, Fernandez-Fresnedo G, Ruiz JC, Pinera C, Cotorruelo, JG, Zubimendi, JA, de Francisco AL Arias M: Circulating levels of matrix metalloproteinases MMP-3 and MMP-2 in renal transplant recipients with chronic transplant nephropathy. Nephrol Dial Transplant 2000;15: 2041-2045. 